\title{
Evidence for an insulin resistance in the adult offspring of pregnant streptozotocin-diabetic rats
}

\author{
K. Holemans, L. Aerts and F. A. Van Assche \\ Department of Obstetrics and Gynaecology, Katholieke Universiteit Leuven, Leuven, Belgium
}

\begin{abstract}
Summary. Our previous work has suggested the presence of an insulin resistance in the adult offspring of streptozotocindiabetic pregnant rats. In this study we used the euglycaemic hyperinsulinaemic clamp technique with an isotope-dilution method to define and quantify this postulated insulin resistance in adult offspring of streptozotocin-diabetic rats. Under basal conditions, these rats had a lower body weight than control rats, but their glucose and insulin concentrations were normal. During the hyperinsulinaemic clamp, the steady-state glucose infusion rate was significantly lower in the offspring of streptozotocin-diabetic rats than in both ageand weight-matched controls, indicating insulin resistance. Basal peripheral tissue glucose utilization was normal in the offspring of streptozotocin-diabetic rats, but the dose-response curve was shifted to the right: insulin concentrations causing half-maximal stimulation of glucose utilization were
\end{abstract}

increased by about $60 \%$ in the offspring of diabetic rats; the maximal stimulation of glucose utilization, however, was unaltered. Basal hepatic glucose production was normal, but again, half-maximal suppression of glucose production occurred at insulin concentrations $50 \%$ higher than in control rats; in addition, the maximal suppression of glucose production was significantly decreased, even at insulin concentrations of $5700 \mu \mathrm{U} / \mathrm{ml}$. These data are evidence for an insulin resistance in the adult offspring of streptozotocin-diabetic rats, characterized by: (1) a decreased insulin sensitivity by peripheral glucose-utilizing tissues, and, (2) a decreased sensitivity and responsiveness of the liver.

Key words: Insulin resistance, euglycaemic hyperinsulinaemic clamp, offspring of streptozotocin-diabetic rats.
Metabolic changes in the pregnant streptozotocindiabetic rat have been shown to affect fetal development and fetal glucose homeostasis [1,2]. A severe hyperglycaemia $(>20 \mathrm{mmol} / \mathrm{l})$ in the maternal rat results in hyperglycaemia and hypoinsulinaemia of their fetuses. On histology and electronmicroscopy, we found evidence of islet hypertrophy, Beta-cell hyperplasia and Beta-cell degranulation in these fetuses: a 'Beta-cell exhaustion phenomenon' is probably the cause of decreased insulin levels in fetal serum $[1,2]$. Malnutrition of the newborn rats by their mothers, causes frequent postnatal death and subnormal glucose and insulin levels in the survivors until weaning $[1,3]$. Body weight in the offspring of severely hyperglycaemic rats is significantly lower than normal from day 20 of gestation and it remains significantly lower during postnatal life: during the lactation period and after weaning [1-3]. The adult offspring of severely hyperglycaemic pregnant rats (SDF-rats) have a normal pancreas on histology and normal serum glucose and insulin concentrations in basal conditions, but their glucose tolerance is clearly impaired [3, 4]. Data from an in vivo ${ }^{123}$ I-insulin captation study would suggest an insulin resistance in SDF-rats [5]. In this study, we used the euglycaemic hyperinsulinaemic clamp method $[6,7]$ to characterize and quantitate the postulated insulin resistance in SDF-rats. With the use of a glucose tracer, we determined the effect of insulin on hepatic glucose production and peripheral glucose utilization, and defined the type of insulin resistance [8].

\section{Material and methods}

\section{Animals}

The animals were adult offspring of control (non-diabetic) and diabetic Wistar (SDF) rats. Diabetes was experimentally induced by an i.v. injection of streptozotocin ( $35 \mathrm{mg} / \mathrm{kg}$ body weight, kindly donated by Upjohn, Puurs, Belgium) on day one of pregnancy (i.e. the day of copulation plug). Severe hyperglycaemia ( $>20 \mathrm{mmol} / \mathrm{l})$ was confirmed in all rats on day 6 and day 20 of gestation.

Only the offspring of rats giving birth to 8 or more pups were included in the study. After weaning the female offspring were kept for 
the study. All the animais had free access to water and a standard rat laboratory chow. Experiments were performed at 100-120 days of age in control $\left(\mathrm{C}_{\mathrm{A}}\right)$ and SDF-rats. Because the body weight of SDFrats was significantly lower than that of the control rats, a weightmatched control group $\left(\mathrm{C}_{\mathrm{W}} ; 60-70\right.$ days of age $)$ was included in the study.

\section{Experimental procedures}

The experiments were started at 12.30 hours; the animals were fasted for $3 \mathrm{~h}$ and were thus in the postabsorptive period. Blood glucose levels were lower in the portal vein than in the carotid artery $\left(4.6 \pm 0.3 \mathrm{mmol} / 1\right.$ vs $4.9 \pm 0.1 \mathrm{mmol} / \mathrm{l}$ in $\mathrm{C}_{\mathrm{A}}$-rats and $4.4 \pm 0.1 \mathrm{mmol} / \mathrm{l}$ vs $4.7 \pm 0.2 \mathrm{mmol} / \mathrm{l}$ in SDF-rats; $p<0.01$ ), indicating that the intestine was not adding glucose to the portal circulation.

Rats were anaesthetized with pentobarbitone $(60 \mathrm{mg} / \mathrm{kg}$, i. p.), the right earotid artery was catheterized for blood sampling and a tracheotomy was performed. Body temperature was continuously recorded and maintained at $37-38^{\circ} \mathrm{C}$.

A $200 \mu \mathrm{l}$ blood sample was taken $30 \mathrm{~min}$ after the end of the surgery to determine basal glucose and insulin concentrations. The euglycaemic hyperinsulinaemic clamp was started as previously described [7], using different doses of insulin $\left(3,10,50 \mathrm{mU} \cdot \mathrm{kg}^{-1} \cdot \mathrm{min}^{-1}\right.$ porcine monocomponent insulin, Novo Industri, Bagsvaerd, Denmark $)$. A primed $(0.3 \mathrm{ml})$ continuous $(20 \mu \mathrm{l} / \mathrm{min})$ infusion of both insulin and D-[3-3 $\mathrm{H}]$-glucose $(40 \mu \mathrm{Ci}$, Amersham Laboratories, Buckinghamshire, UK) was given through the right saphenous vein. A variable glucose infusion $(10,20$ or $30 \%$ solution) was administered through the same saphenous vein $1 \mathrm{~min}$ after starting the insulin infusion. Blood glucose levels were measured every 5 min (Yellow Spring glucose analyser $23 \mathrm{~A}$, Yellow Spring, Ohio, USA) and the glucose infusion rate was adjusted accordingly to maintain euglycaemia. Steady state was usually reached after $40 \mathrm{~min}$ and was maintained during $20 \mathrm{~min}$. Three $200 \mu \mathrm{l}$ blood samples were collected, at 5 to $10 \mathrm{~min}$ intervals, for triplicate determination of glucose and insulin concentrations and glucose specific activity. Non-esterified fatty acids (NEFA) and glucagon were determined on the final blood sample.

Endogenous glucose production was determined with an isotope dilution method [9] using D- $\left[3-{ }^{3} \mathrm{H}\right]$-glucose as a tracer because tritium in position three of the glucose molecule is lost to water in the glycolytic pathway and cannot be reincorporated into glucose [10]. $\mathrm{D}-\left[3-{ }^{3} \mathrm{H}\right]$-glucose is thus considered to be an irreversible tracer. In the basal state, glucose turnover rate was determined by a primed $\left(4 \mu \mathrm{Ci}\right.$ of $\mathrm{D}-\left[3-{ }^{3} \mathrm{H}\right]$-glucose in $\left.2 \mathrm{~min}\right)$, continuous infusion $(0.2 \mu \mathrm{Ci}$ D- $\left[3-{ }^{3} \mathrm{H}\right]-$ glucose $\left.\cdot \mathrm{min}^{-1}\right)$ of the glucose tracer. Steady state of the blood glucose specific activity was established after $30 \mathrm{~min}$ (unpublished observations). During the clamp studies, a steady state for glucose specific activity prevailed during the last $20 \mathrm{~min}$ of insulin infusion (unpublished observations).

\section{Analytical techniques}

Part of each blood sample was deproteinized with $\mathrm{Ba}(\mathrm{OH})_{2}-\mathrm{ZnSO}_{4}$ and centrifuged. An aliquot of the supernatant was used for determination of blood glucose concentration according to the D-glucoseoxidase D-peroxidase procedure (GOD-PAP, Boehringer Mannheim, FRG). Another aliquot was evaporated to dryness at $60^{\circ} \mathrm{C}$ to remove ${ }^{3} \mathrm{H}_{2} \mathrm{O}$; the dry residue was dissolved in $200 \mu \mathrm{l}$ aq. dist. and counted in a liquid scintillation counter (Packard Co., Canberra, Australia).

Blood samples for determination of insulin, glucagon and NEFA concentration were centrifuged and the plasma was frozen at $-20^{\circ} \mathrm{C}$. Insulin concentrations were measured by radioimmunoassay using a rat and porcine insulin standard (Novo Industri), NEFA were determined using an enzymatic method (enzyme kit, Boehringer Mannheim, FRG) and glucagon by radioimmunoassay (glucagon kit, Medgenix, Fleurus, Belgium).

\section{Calculations and statistical analysis}

In the basal state and during the clamp studies, glucose appearance rate $(\mathrm{Ra})$ equals glucose disappearance rate $(\mathrm{Rd})$ at dynamic equilibrium. Both rates were calculated with the isotope dilution equation: $\mathrm{Ra}=\mathrm{Rd}=\mathrm{F} / \mathrm{SA}$, where $\mathrm{F}$ is the tracer infusion rate $(\mathrm{dpm} / \mathrm{min})$ and SA the blood glucose specific activity (dpm/mg) under steady state conditions [7]. In the basal state Ra equals hepatic glucose output and $R d$ equals glucose utilization. During the euglycaemic hyperinsulinaemic clamp, Ra represents the sum of endogenous glucose production and exogenous glucose infusion rate and $\mathrm{Rd}$ represents the rate of glucose utilization. The rate of endogenous glucose production was obtained by subtracting the amount of exogenous glucose infused from the isotopically determined $\mathrm{Rd}$, which equals $\mathrm{Ra}$ at dynamic equilibrium.

Values are given as means \pm SEM. A univariate frequency distribution test was performed on all data. Analysis of variance determined whether the three groups of animals differed significantly. If analysis of variance indicated that the three groups were different, $t$-tests were performed to assess the significance of the difference between two specific group means.

\section{Results}

All pregnant rats were severely hyperglycaemic and hypoinsulinaemic (Table 1). The adult offspring of these rats had a decreased body weight, but their non-fasting glucose and insulin levels were within the normal range (Table 2).

Table 1. General features of rats on day 20 of gestation

\begin{tabular}{lll}
\hline & Control & Diabetic \\
\hline Body weight & $291 \pm 3$ & $273 \pm 4^{\mathrm{a}}$ \\
$(\mathrm{g})$ & $(16)$ & $(11)$ \\
Glucose & $4.3 \pm 0.2$ & $22.5 \pm 1.4^{\mathrm{b}}$ \\
(mmol/l) & $(16)$ & $(11)$ \\
Insulin & $55 \pm 5$ & $12 \pm 1^{\mathrm{b}}$ \\
$(\mu \mathrm{U} / \mathrm{ml})$ & $(15)$ & $(11)$ \\
\hline
\end{tabular}

Values are means \pm SEM. Number of animals is given within parentheses.

${ }^{\mathrm{a}} p<0.01,{ }^{\mathrm{b}} p<0.0001$, vs controls

Table 2. General features of adult offspring of control and severely diabetic rats

\begin{tabular}{llll}
\hline & $\begin{array}{l}\text { Control } \\
\text { age-matched } \\
\left(\mathrm{C}_{\mathrm{A}}\right)\end{array}$ & $\begin{array}{l}\text { Control } \\
\text { weight-matched } \\
\left(\mathrm{C}_{\mathrm{W}}\right)\end{array}$ & $\begin{array}{l}\text { Diabetes } \\
(\mathrm{SDF})\end{array}$ \\
\hline Age & $100-120$ & $<100$ & $100-200$ \\
(days) & $(35)$ & $(17)$ & $(33)$ \\
Body weight & $214 \pm 3$ & $184 \pm 2^{\mathrm{a}}$ & $177 \pm 3^{\mathrm{a}}$ \\
(g) & $(35)$ & $(17)$ & $(33)$ \\
Glucose & $5.4 \pm 0.1$ & $5.4 \pm 0.1$ & $5.7 \pm 0.2$ \\
(mmol/1) & $(35)$ & $(17)$ & $(31)$ \\
Insulin & $24 \pm 2$ & $23 \pm 2$ & $24 \pm 3$ \\
$(\mu \mathrm{U} / \mathrm{ml})$ & $(23)$ & $(17)$ & $(27)$ \\
\hline
\end{tabular}

$\mathrm{C}_{\mathrm{A}}$ : age-matched controls; $\mathrm{C}_{\mathrm{W}}$ : weight-matched controls; $\mathrm{SDF}$ : adult offspring of severely diabetic rats. Values are means \pm SEM. Number of animals is given within parentheses.

${ }^{a} p<0.0001$, vs age-matched controls 


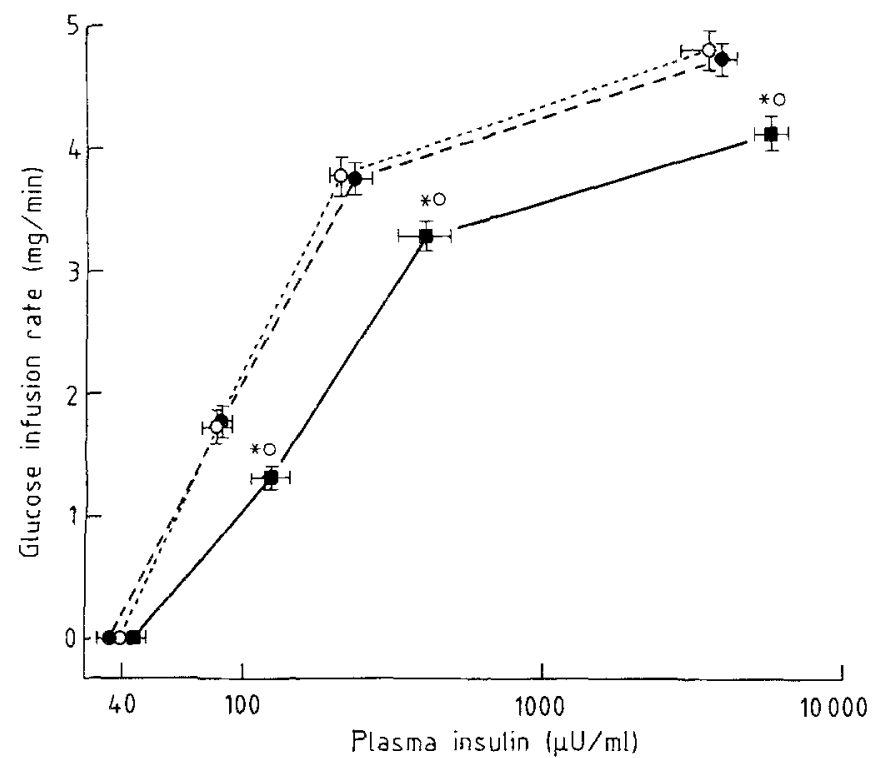

Fig. 1. Insulin dose-response curves for steady state giucose infusion rate in age-matched controls $\left(\mathrm{C}_{\mathrm{A}}:-\cdots\right)$, weight-matched controls $\left(\mathrm{C}_{\mathrm{W}}: \mathrm{O}\right.$---O) and adult offspring of streptozotocin-diabetic rats (SDF: - - Values are means \pm SEM of 5-11 experiments. $*: p<0.05$ vs age-matched controls; ${ }^{0}: p<0.05$ vs weight-matched controls

\section{Clamp studies}

During the clamps, blood glucose concentrations were maintained at $98 \%$ of the basal euglycaemic level, with a standard deviation of $6 \%$. The coefficient of variation of blood glucose concentrations during the clamp period was $4.25 \pm 0.17 \%$.

To determine the sensitivity of total-body glucose metabolism to insulin, steady state glucose infusion rates required to maintain euglycaemia, were plotted semilogarithmically vs the corresponding steady state plasma insulin concentrations. The glucose infusion rate was significantly lower in SDF-rats than in $\mathrm{C}_{\mathrm{A}}$-rats $(p<0.001$, $p<0.02$ and $p<0.01$ at insulin infusion rates of 3,10 and $50 \mathrm{mU} \cdot \mathrm{kg}^{-1} \cdot \mathrm{min}^{-1}$, respectively) and in $\mathrm{C}_{\mathrm{W}}$-rats $(p<0.01$ at insulin infusion rates of 3,10 and $50 \mathrm{mU}$. $\left.\mathrm{kg}^{-1} \cdot \min ^{-1}\right)$ (Fig. 1). The dose-response curve was clearly shifted to the right in SDF-rats (Fig. 1).

\section{Dose-response characteristics for the effect of insulin on glucose utilization and glucose production}

Basal rates of glucose utilization were not significantly different between the different groups (Fig. 2). In SDF-rats, the dose-response curve was shifted to the right: insulin concentration at half-maximal stimulation of glucose utilization was increased from about $120 \mu \mathrm{U} / \mathrm{ml}$ to $200 \mu \mathrm{U} / \mathrm{ml}$. Maximal stimulation of glucose utilization was not altered in SDF-rats. Glucose utilization increased from a basal rate of $1.97 \pm 0.10 \mathrm{mg} / \mathrm{min}, \quad 2.18 \pm 0.11 \mathrm{mg} / \mathrm{min}$, and $1.95 \pm 0.10 \mathrm{mg} / \mathrm{min}$ to a maximum of $4.89 \pm 0.07 \mathrm{mg} / \mathrm{min}$, $4.86 \pm 0.14 \mathrm{mg} / \mathrm{min}$ and $4.90 \pm 0.13 \mathrm{mg} / \mathrm{min}$ at plasma insulin concentrations of $3870 \pm 320 \mu \mathrm{U} / \mathrm{ml}, 3530 \pm$ $600 \mu \mathrm{U} / \mathrm{ml}$ and $5730 \pm 760 \mu \mathrm{U} / \mathrm{ml}$ in respectively $\mathrm{C}_{\mathrm{A}^{-}}, \mathrm{C}_{\mathrm{W}^{-}}$, and SDF-rats (Fig. 2 and Table 3).

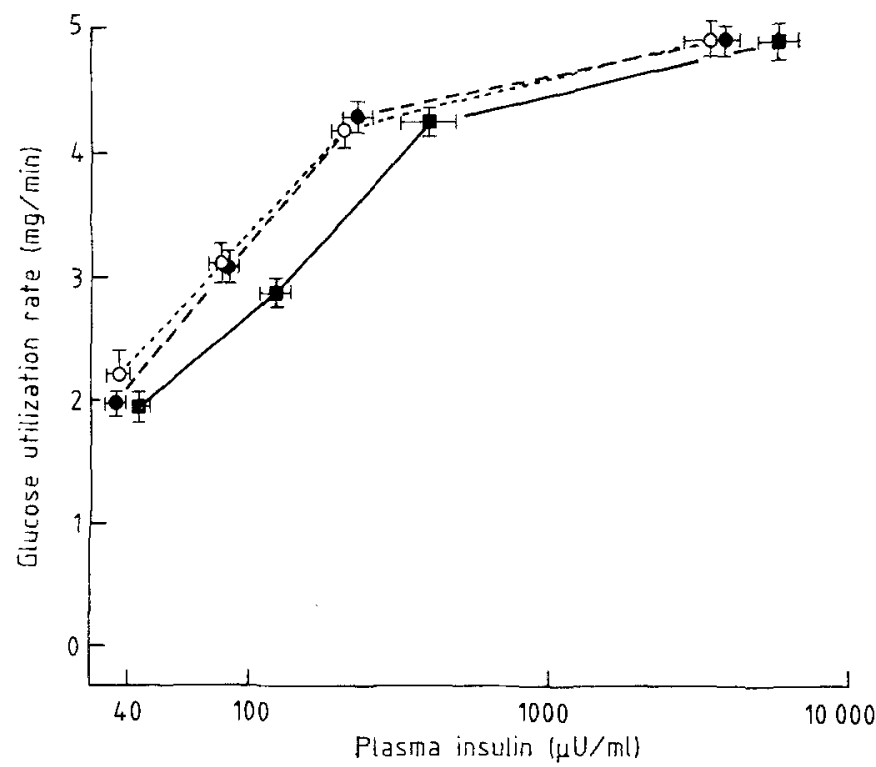

Fig. 2. Insulin dose-response curves for stimulation of glucose utilization in age-matched controls $\left(\mathrm{C}_{\mathrm{A}}:-\cdots\right)$, weight-matched controls $\left(\mathrm{C}_{\mathrm{W}}: \mathrm{O}--\mathrm{O}\right)$ and adult offspring of streptozotocin-diabetic rats (SDF:

- $)$. Values are means \pm SEM of 5-11 experiments

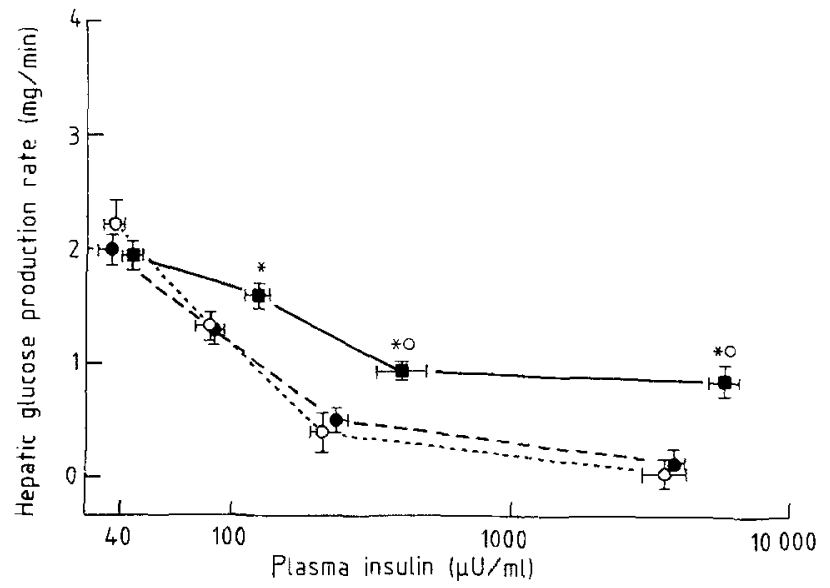

Fig. 3. Insulin duscircsponse curves tor indibition of endogenous glucose production in age-matched controls $\left(\mathrm{C}_{\mathrm{A}}\right.$ : $\left.-\cdots\right)$, weightmatched controls $\left(\mathrm{C}_{\mathrm{w}}: \mathrm{O}-\cdots\right)$ ) and adult offspring of streptozotocindiabetic rats (SDF: - ). Values are means \pm SEM of $5-11$ experiments. *: $p<0.05$ vs age-matched controls; 0 : $p<0.05$ vs weight-matched controls

The basal rate of glucose production was similar in the three groups (Fig. 3). The dose-response curve was also shifted to the right in SDF-rats: insulin concentrations at half-maximal suppression of glucose production were increased by about $70 \%$ (from $110 \mu \mathrm{U} / \mathrm{ml}$ to $180 \mu \mathrm{U} / \mathrm{ml}$ ). In addition, the maximal suppression of endogenous glucose production was significantly decreased in SDF-rats $(0.84 \pm 0.05 \mathrm{mg} / \mathrm{min})$ than in $\mathrm{C}_{\mathrm{A}}$-rats $(0.16 \pm 0.04 \mathrm{mg} / \mathrm{min}$; $p<0.001)$ and in $\mathrm{C}_{\mathrm{W}}$-rats $(0.07 \pm 0.08 \mathrm{mg} / \mathrm{min} ; p<0.001)$.

Basal plasma glucagon concentrations (Table 3 ) were not significantly different in SDF-rats and in $\mathrm{C}_{\mathrm{A}^{-}}$and $\mathrm{C}_{\mathrm{X}}$ rats. Hyperinsulinaemia decreased plasma glucagon concentrations to the same extent in the three groups of animals: after an insulin infusion rate of $50 \mathrm{mU} \cdot \mathrm{kg}^{-1} \cdot \mathrm{min}^{-1}$ 
Table 3. Blood glucose, plasma insulin, NEFA and glucagon in basal conditions and during euglycaemic hyperinsulinaemic clamp

\begin{tabular}{|c|c|c|c|c|c|c|c|}
\hline $\begin{array}{l}\text { Insulin dose } \\
\mathrm{mU} \cdot \mathrm{kg}^{-1} \cdot \mathrm{min}^{-1}\end{array}$ & $\begin{array}{l}\mathrm{BPI} \\
\mu \mathrm{U} / \mathrm{ml}\end{array}$ & $\begin{array}{l}\text { SSPI } \\
\mu \mathrm{U} / \mathrm{ml}\end{array}$ & $\begin{array}{l}\mathrm{BBG} \\
\mathrm{mmol} / 1\end{array}$ & $\begin{array}{l}\mathrm{SSBG} \\
\mathrm{mmol} / 1\end{array}$ & $\begin{array}{l}\text { Glucagon } \\
\mathrm{pg} / \mathrm{ml}\end{array}$ & $\begin{array}{l}\mathrm{NEFA} \\
\mathrm{mmol} / \mathrm{l}\end{array}$ & $n$ \\
\hline \multicolumn{8}{|c|}{ Age-matched controls $\left(\mathrm{C}_{\mathrm{A}}\right)$} \\
\hline 3 & $53 \pm 3$ & $86 \pm 4$ & $4.7 \pm 0.2$ & $4.7 \pm 0.2$ & $115 \pm 19$ & $0.23 \pm 0.02$ & 10 \\
\hline 10 & $51 \pm 5$ & $235 \pm 18$ & $4.9 \pm 0.1$ & $4.8 \pm 0.1$ & $88 \pm 19$ & $0.23 \pm 0.06$ & 9 \\
\hline 50 & $48 \pm 3$ & $3871 \pm 321$ & $5.0 \pm 0.1$ & $4.8 \pm 0.1$ & $76 \pm 14$ & $0.11 \pm 0.03$ & 11 \\
\hline \multicolumn{8}{|c|}{ Weight - matched controls $\left(\mathrm{C}_{\mathrm{W}}\right)$} \\
\hline 3 & $43 \pm 4$ & $83 \pm 7$ & $4.8 \pm 0.1$ & $4.8 \pm 0.2$ & $119 \pm 22$ & $0.24 \pm 0.03$ & 5 \\
\hline 10 & $45 \pm 6$ & $213 \pm 16$ & $5.0 \pm 0.2$ & $4.9 \pm 0.2$ & $85 \pm 16$ & $0.21 \pm 0.05$ & 5 \\
\hline 50 & $39 \pm 3$ & $3527 \pm 604$ & $4.8 \pm 0.1$ & $4.9 \pm 0.1$ & $75 \pm 17$ & $0.14 \pm 0.04$ & 5 \\
\hline \multicolumn{8}{|c|}{ Adult offspring of severely diabetic mothers (SDF) } \\
\hline 0 & $44 \pm 4$ & & $4.8 \pm 0.1$ & & $101 \pm 13$ & $0.34 \pm 0.03^{\mathrm{a}, \mathrm{b}}$ & 8 \\
\hline
\end{tabular}

$\mathrm{BPI}=$ basal plasma insulin; SSPI = steady state plasma insulin; $\mathrm{BBG}=$ basal blood glucose; $\mathrm{SSBG}=$ steady state blood glucose; $\mathrm{NEFA}=$ steady state plasma non-esterified fatty acids; Glucagon = steady state plasma glucagon.

Values are means \pm SEM. a $p<0.05$, vs age-matched controls; ${ }^{b} p<0.05$, vs weight-matched controls

the percentage decrease from basal values was $42 \%, 46 \%$ and $45 \%$ in respectively $\mathrm{C}_{\mathrm{A}^{-}}, \mathrm{C}_{\mathrm{W}^{-}}$and $\mathrm{SDF}$-rats.

NEFA levels, which were significantly lower in the basal state in SDF-rats compared to $\mathrm{C}_{\mathrm{A}^{-}}$and $\mathrm{C}_{\mathrm{W}}$-rats $(p<0.01$, respectively $p<0.05$ ), decreased less during the different clamps in SDF-rats and became similar to those of the control rats (Table 3 ).

\section{Discussion}

An insulin resistance was suggested by data showing that SDF-rats, during an i.v. glucose infusion, maintained glucose levels within the control range in the presence of increased insulin levels [4]. Moreover, in vivo ${ }^{123}$ T-insulin captation studies in these rats demonstrated an elevated renal clearance of insulin, which also suggests a decreased uptake of insulin by peripheral tissues [5]. In the same study, we found that islets of Langerhans were more sensitive to glucose in vitro in SDF-rats than in control rats [5]; it was then postulated that this hypersecretion of insulin was the consequence of an insulin resistance.

We confirmed that SDF-rats, at 100 days of age, had a lower body weight than control rats, and that they maintained normal glucose and insulin levels in basal conditions $[3,4]$. Furthermore, we found a normal basal glucose utilization by peripheral tissues and a normal basal glucose production by the liver in SDF-rats. This finding is compatible with our previous data showing that these adult offspring appear to have recovered quite well from the influences of the abnormal perinatal milieu, at least under basal conditions [3].

The present results indicate that, using the definitions of Kahn [8], the peripheral tissues of SDF-rats are less sensitive (decreased half-maximal effect) to insulin, thus confirming our previous results of ${ }^{123} \mathrm{I}$-insulin captation experiments [5]. On a weight basis, skeletal muscle is the most important glucose-utilizing tissue [11]. In man, it has been demonstrated that skeletal muscles are primarily responsible for the disposal of an intravenous glucose load in an euglycaemic clamp [12].

It is most likely that also in SDF-rats skeletal muscle is primarily involved in the peripheral insulin resistance (work in progress). Since all the rats were in the postabsorptive state, the glucose production rate in these studies equals the actual hepatic glucose production rate. The results indicate that, in SDF-rats, the liver is less sensitive (decreased half-maximal effect) and also less responsive (decreased maximal effect) to insulin.

By including weight-matched control rats, we demonstrated that the $17 \%$ decrease of body weight in SDF-rats compared to controls is not responsible for the observed effects on glucose utilization and glucose production.

The exact cause of this hepatic and peripheral insulin resistance is unknown at present. Insulin action on target tissues might be altered by a decreased receptor number and/or affinity, or by a post-receptor defect $[13,14]$. Changes in the levels of counterregulatory hormones could also be involved, e. g. glucagon stimulates insulin-inhibited hepatic glucose production [14]. In the basal state and during hyperinsulinaemia glucagon levels are not significantly different in SDF-rats and control rats. This suggests that glucagon is probably not involved in the hepatic insulin resistance observed in SDF-rats. Elevated NEFA concentrations are known to reduce insulin-stimulated glucose disposal, especially in muscles [15]. Although NEFA levels are lower in basal conditions in SDF-rats, hyperinsulinaemia decreased plasma NEFA to a lesser extent in SDF-rats than in $\mathrm{C}_{\mathrm{A}^{-}}$and $\mathrm{C}_{\mathrm{W}}$-rats. However, plasma NEFA concentrations do not reach significantly higher levels during extreme hyperinsulinaemia in SDFrats. This suggests that NEFA do not inhibit glucose utilization in SDF-rats.

Further studies should also concentrate on the developmental origin of these changes. The insulin resistance could well be the result of the significant metabolic 
changes in the diabetic intra-uterine milieu. The last days of fetal life are a critical period for the maturation of the insulin receptor and the post -receptor events in the rat $[16,17]$. Hypoinsulinaemia, as found in fetuses of severely diabetic rats $[1,2,18]$ might affect the receptor ontogenesis: the specific binding of insulin to liver and lung membranes of fetuses of severely diabetic rats was, indeed, found to be decreased [19]. The postnatal milieu also might be involved. Due to nutritional deficiency in the lactation period, the body weight, glucose levels and therefore also insulin levels are below normal $[1,3]$. These hypoinsulinaemic levels might also affect the sites of insulin action in the neonate.

Streptozotocin, given to the maternal rat, in early pregnancy is almost certainly not the cause of these changes, because streptozotocin has a very short half-life [20]. Secondly, similar metabolic changes have been reported in fetuses of rats, made hyperglycaemic by a glucose infusion $[21,22]$ and in the spontaneously diabetic $\mathrm{BB}$ rat [18]. Genetic transmission of the defect is also excluded because the offspring of streptozotocin-diabetic fathers do not show changes in glucose homeostasis [23].

Although a hyperglycaemia of such severity is rarely found in humans, these data suggest that poorly controlled diabetes during pregnancy can affect the glucose-insulin homeostasis in the next generation. Studies in Pima Indians have already shown that, in addition to a genetic transmission of diabetes, the diabetic intra-uterine milieu increases the incidence of an impaired glucose tolerance in children of gestational diabetic mothers [24].

In conclusion, the present study gives evidence for an insulin resistance in the adult offspring of severely diabetic pregnant rats, characterized by: (1) a decreased insulin sensitivity at the peripheral tissues, and (2) a decreased insulin sensitivity and responsiveness of the liver.

Acknowledgements. We are deeply indebted to Dr. J. Girard (CNRS, Paris) for giving us the possibility to learn the clamp technique in his laboratory. We wish to thank Dr. J. Verhaeghe for critically reviewing the manuscript. The technical assistance of Ms. R. van Bree is gratefully acknowledged.

\section{References}

1. Aerts L, Van Assche FA (1977) Rat fetal endocrine pancreas in experimental diabetes. J Endocrinol 73: 339-346

2. Kervran A, Guillaume M, Jost (1978) The endocrine pancreas of the fetus from diabetic pregnant rat. Diabetologia 15:387-393

3. Aerts L, Van Assche FA (1981) Endocrine pancreas in the offspring of rats with experimentally induced diabetes. J Endocrinol 88: $81-88$

4. Van Assche FA, Aerts L (1985) Long term effect of diabetes and pregnancy in the rat. Is acquired insulin resistance responsible? Diabetes 85: 590-597

5. Aerts L, Sodoyez-Goffaux F, Sodoyez JC, Malaisse WJ, Van Assche FA (1988) The diabetic intrauterine milieu has a longlasting effect on insulin secretion by B cells and insulin uptake by target tissues. Am J Obstet Gynecol 159: 1287-1292
6. DeFronzo RA, Tobin JD, Andres R (1979) Glucose clamp technique: a method for quantifying insulin secretion and resistance. Am J Physiol 237: E214-E223

7. Burnol A-F, Leturque A, Ferré P, Girard J (1983) A method for quantifying insulin sensitivity in vivo in the anesthetized rat: the euglycemic clamp technique coupled with isotopic measurement of glucose turnover. Reprod Nutr Develop 23: 429-435

8. Kahn CR (1978) Insulin resistance, Insulin insensitivity and insulin unresponsiveness: a necessary distinction. Metabolism 27: 1893-1902

9. Steele R, Watt JS, de Bodo RC, Altzhuler N (1956) Measurement of size and turnover rate of body glucose pool by the isotope dilution method. Am J Physiol 187: 15-24

10. Altzhuler N, Barkai A, Bjerknes C, Gottlieb B, Steele R (1975) Glucose turnover values in the dog obtained with various species of labeled glucose. Am J Physiol 229: 1662-1667

11. Curtis-Prior PB, Trethewey J, Stewart GA, Hauley T (1969) The contribution of different organs and tissues of the rat to assimilation of glucose. Diabetologia 5: 384-391

12. DeFronzo RA, Jacot E, Jaequier E, Maeder E, Wahrem J, Felber JP (1981) The effect of insulin on the disposal of intravenous glucose. Diabetes 30: 1000-1007

13. Olefsky JM (1975) Effect of dexamethasone on insulin binding, glucose transport and glucose oxidation of isolated rat adipocytes. J Clin Invest 56: 1499-1508

14. Olefsky JM (1981) Insulin resistance and insulin action: an in vitro and in vivo perspective. Diabetes 30: 148-161

15. Randle P, Garland P, Hales C, Newsholme E, Denton R, Pogson $C$ (1966) Interactions of metabolism and the physiological role of insulin. Recent Prog Horm Res 22: 1-48

16. Autiori F, Baldini P, Ciofi Luzzatto A, Conti Divirglus L, Incerpi S, Luly $\mathrm{P}$ (1981) Insulin binding and internalization during prenatal and postnatal life. Biochim Biophys Acta 678: 1-6

17. Sodoyez-Goffaux F, Sodoyez JC, Devos CJ (1982) Maturation of liver handling of insulin in the rat fetus. Diabetes 31: 60-69

18. Verhaeghe J, Peeters TL, Vandeputte M, Rombauts W, Bouillon R, Van Assche FA (1989) Maternal and fetal endocrine pancreas in the spontaneously diabetic BB rat. Biol Neonate 55: 298-308

19. Mulay S, Philip A, Salomon S (1983) Influence of maternal diabetes on fetal rat development: alteration of insulin receptors in fetal liver and lung. J Endocrinol 98: 401-410

20. Schein PS, Loftus S (1968) Streptozotocin: depression of mouse liver pyridine nucleotides. Cancer Res 28: 1501

21. Bihoreau MT, Ktorza A, Kervran A, Picon L (1986) Effect of gestational hyperglycemia on insulin secretion in vivo and in vitro by fetal rat pancreas. Am J Physiol: E86-E91

22. Bihoreau MT, Ktorza A, Kinebanyan MF, Picon L (1986) Impaired glucose homeostasis in adult rats from hyperglycemic mothers. Diabetes 35: 979-984

23. Van Assche FA, Aerts L (1985) Long term effect of diabetes and pregnancy in the rat. Diabetes 34: 116-118

24. Pettitt DJ, Aleck KA, Baird HR, Carraher MJ, Bennett PH, Knowler WC (1988) Congenital susceptibility to NIDDM. Role of intrauterine environment. Diabetes 37: 622-628

Received: 2 April 1990

and in revised form: 14 September 1990

Dr. K. Holemans

Department Obstetrics and Gynaecology

U.Z. Gasthuisberg St. Rafael

Herestraat 49

B-3000 Leuven

Belgium 